\title{
RAGAM BAHASA DALAM KISAH INSPIRATIF INDONESIA MENGAJAR
}

\author{
Oleh: \\ Intan Berliana Singamou \\ (Pendidikan Bahasa dan Sastra Indonesia, Fakultas Keguruan dan Ilmu Pendidikan, Universitas PGRI Adi Buana \\ Surabaya) \\ intanbsingamou@gmail.com \\ Luluk Isani Kulup \\ (Dosen Program Studi Pendidikan Bahasa dan Sastra Indonesia, Fakultas Keguruan dan Ilmu Pendidikan, \\ Universitas PGRI Adi Buana Surabaya) \\ kulupluluk@gmail.com
}

\begin{abstract}
This research is motivated by the diversity or kevariasian language contained in a region. As a tool for expressing thoughts and feelings, the choice of language varieties largely determines what the audience is saying is understood or not. In the Inspirational story of Indonesia teaching, there are people who have more than one language, and speakers also come from unequal regions or regions, so speakers have to choose exactly which languages to use. The purpose of this study is to describe the variation of language in the Indonesian Inspirational story of teaching. This research uses qualitative approach with description method. Data collection techniques used in this study is documentation. Then, the data is analyzed in accordance with the existing procedure. The object of this research is the utterance or speech of the characters in the story Inspiratif Indonesia teaching. The results of this study indicate that, in speaking or communicating, the characters or speakers in the Indonesian Inspirational taught to choose or use a variety of language based on situations, speech partners, habits, and age, so they tend to use non-formal language variety in saying or communicating. The variety of languages used in the Indonesian Inspirational story teaching is a variety of business or consultative variety, casual or casual variety, intimate or intimate variety, literature, and literary variety.
\end{abstract}

Keywords : sociolinguistics, language variation, language variety.

\section{PENDAHULUAN}

Bahasa adalah sistem lambang bunyi yang arbitrer yang dipergunakan oleh masyarakat untuk kerja sama, berinteraksi, dan mengidentifikasikan diri, Kridalaksana (dalam Aslinda dan Leni, 2014: 1). Pengkajian bahasa dengan dimensi kemasyarakatan disebut sosiolinguistik, Nababan (dalam Chaer dan Agustina, 2010: $3)$.

Sosiolinguistik adalah subdisiplin linguistik yang mempelajari bahasa dalam hubungan pemakaiannya di masyarakat (Chaer, 2012: 16). Dalam sosiolinguistik ini, antara lain, dibicarakan pemakai dan pemakaian bahasa, tempat pemakaian bahasa, tata tingkat bahasa, berbagai akibat adanya kontak dua bahasa atau lebih, dan ragam serta waktu pemakaian ragam bahasa itu.

Setiap bahasa digunakan oleh sekelompok orang yang termasuk dalam suatu masyarakat bahasa. Anggota masyarakat suatu bahasa biasanya terdiri dari berbagai orang dengan berbagai status sosial dan berbagai latar belakang budaya yang tidak sama. Anggota masyarakat bahasa itu ada yang berpendidikan ada yang tidak; ada yang tinggal di kota ada yang tinggal di desa; ada orang dewasa ada pula kanak-kanak. Ada yang berprofesi dokter, petani, pegawai kantor, nelayan dan sebagainya. Oleh karena itu, karena latar belakang dan lingkungannya yang tidak 
sama, maka bahasa yang mereka gunakan menjadi bervariasi atau beragam, di mana antara variasi atau ragam yang satu dengan yang lain seringkali mempunyai perbedaan yang besar.

Mengenai variasi bahasa ini ada tiga istilah yang perlu diketahui, yaitu idiolek, dialek, dan ragam. Ragam atau ragam bahasa adalah variasi bahasa yang digunakan dalam situasi, keadaan, atau untuk keperluan tertentu (Chaer, 2012: 55). Dari sarana yang digunakan dapat dibedakan adanya ragam lisan dan ragam tulisan. Juga ada ragam bahasa bertelepon, ragam bahasa bertelegram, dan sebagainya. Untuk keperluan pemakaiannya dapat dibedakan adanya ragam bahasa ilmiah, ragam bahasa jurnalistik, ragam bahasa sastra, ragam bahasa militer, dan ragam bahasa hukum. Untuk situasi formal digunakan ragam bahasa yang disebut ragam baku atau ragam standar; untuk situasi yang tidak formal digunakan ragam yang tidak baku atau ragam nonstandar.

Terjadinya keragaman atau kevariasian bahasa ini bukan hanya disebabkan oleh para penuturnya yang tidak homogen, tetapi juga kegiatan interaksi sosial yang mereka lakukan sangat beragam.

Sebuah contoh ragam bahasa dalam masyarakat dapat ditemukan pada tuturan para tokoh dalam kisah inspiratif Indonesia Mengajar.

Enceng :"Bu, Maya pusing katanya." "Bu, saya nggak bisa duduk. Ini Maya tidur di kursi saya, Bu."

Bu Guru : "Maya sakitkah?" "Kalau Maya tidur, Enceng nggak bisa duduk."

Enceng: "Bu, Maya nggak mau nulis."

Bu Guru : "Maya, semua harus menulis, yang nggak menulis nanti nggak dapat nilai."

Enceng: "Bu, Maya nggak nulis."

$\mathrm{Bu}$ Guru : "Maya harus nulis sendiri, Ibu nggak mau memberi nilai kalau bukan tulisan Maya sendiri."

Maya : "Hwaaaa ......."
Percakapan di atas adalah percakapan antara guru dan anak didiknya yang terjadi di dalam kelas. Dalam tuturan para tokoh ini, terdapat dua ragam bahasa, yaitu ragam formal yang hanya digunakan dalam situasi resmi, dan ragam usaha atau ragam konsultatif yang disisipi dalam percakapan di atas. Ragam usaha atau ragam konsultatif ini lazim digunakan dalam pembicaraan biasa di sekolah. Wujud ragam usaha ini berada di antara ragam formal dan ragam informal atau ragam santai.

Ragam bahasa yang terdapat dalam suatu masyarakat menjadi salah satu fenomena kebahasaan yang menarik untuk diteliti. Seperti contoh ragam bahasa pada percakapan di atas membuat penulis tertarik untuk meneliti lebih lanjut variasi bahasa yang terdapat dalam kisah inspiratif Indonesia Mengajar.

Penulis tertarik untuk meneliti ragam bahasa karena sebagai alat untuk mengekspresikan pikiran dan perasaan seseorang kepada yang orang lain, pemilihan atau penggunaan bahasa sangat menentukan apa yang disampaikan dimengerti orang yang mendengar atau tidak. Masyarakat di suatu tempat atau daerah memiliki bahasa yang berbeda dengan masyarakat di daerah lain. Komunikasi atau interaksi akan berjalan lancar karena mereka sama-sama mengerti bahasa yang digunakan, namun bagaimana jika dalam suatu daerah terdapat beberapa kelompok masyarakat yang berbeda asal atau daerahnya, yang hidup berdampingan. Selain menggunakan bahasa Indonesia sebagai bahasa pemersatu, masing-masing kelompok ini memiliki bahasa lain yang digunakan juga dalam berinteraksi. Penggunaan ragam bahasa dalam suatu masyarakat yang tinggal bersama, namun berasal dari daerah yang berbeda membuat penulis tertarik untuk menelitinya

Dalam penelitian ini, penulis meneliti ragam bahasa dalam kisah inspiratif Indonesia Mengajar. Penulis memilih kisah inspiratif Indonesia Mengajar karena buku 
ini berisi tentang kisah-kisah para pengajar muda yang meneguhkan niat mereka untuk berjuang mencerdaskan kehidupan bangsa dengan suatu pengorbanan yang besar. Mereka meninggalkan keluarga, temanteman, kenyamanan, dan kemapanan kota dan memilih untuk mengabdi di desa-desa terpencil yang sebagian besar belum ada listrik ataupun sinyal telepon seluler. Membaca kisah-kisah mereka sangat menginspirasi saya sebagai calon pengajar dan dapat menginspirasi orang lain untuk turut melunasi sebuah janji kemerdekaan: mencerdaskan kehidupan bangsa, seperti kata M. Arsjad Rasjid P.M. "Pendidikan harus melibatkan semua orang karena mendidik adalah tugas setiap orang terdidik". Dari kisah ini juga saya dapat mengetahui tantangan-tantangan yang mungkin akan saya hadapi kelak, dan mengetahui bagaimana menghadapi atau menyelesaikan tantangan yang ada.

Tujuan penelitian ini adalah untuk mendeskripsikan variasi bahasa dalam kisah inspiratif Indonesia Mengajar.

Dengan adanya penelitian ini, diharapkan dapat menambah pengetahuan pembaca dalam bidang sosiolinguistik khusunya variasi bahasa, dan mengetahui wujud variasi bahasa dalam kisah inspiratif Indonesia Mengajar. Penelitian ini juga dapat dipakai oleh guru sebagai bahan bacaan. Guru harus menggunakan bahasa ragam resmi atau bahasa formal dalam pembelajaran, karena pembelajaran di sekolah adalah situasi formal. Penggunaan bahasa yang tepat sangat mendukung tersampainya pesan atau informasi dengan baik kepada peserta didik. Adanya penelitia ini dapat membantu guru untuk bisa memilih dan menggunakan ragam bahasa yang tepat dalam situasi-situasi tertentu.

Selain manfaat-manfaat di atas, terdapat pula manfaat lain, yaitu penelitian ini dapat dipakai sebagai sumber ide bagi pembaca atau peneliti lain yang akan melakukan penelitian atau menulis tentang bahasa.
Penelitian ini menggunakan teori Chaer dan Agustina yang membedakan variasi bahasa berdasarkan segi penutur yang penutur dibagi menjadi empat jenis, yakni variasi bahasa yang bersifat perseorangan (idiolek), variasi bahasa dari sekelompok penutur yang jumlahnya relatif yang berada pada satu tempat, wilayah, atau area tertentu (dialek), variasi bahasa yang digunakan oleh sekelompok sosial pada masa tertentu (kronolek), dan variasi bahasa yang berkenaan dengan status, golongan, dan kelas sosial para penuturya (sosiolek); segi pemakaian, yakni variasi bahasa yang berkenaan dengan penggunaannya, pemakaiannya, atau fungsinya; segi keformalan yang terbagi atas beberapa ragam bahasa, yaitu ragam bahasa beku, ragam bahasa resmi, ragam bahasa usaha, ragam bahasa santai, dan ragam bahasa akrab; dan segi sarana, yakni dilihat dari sarana yang digunakan, terdapat ragam bahasa lisan dan ragam bahasa tulisan.

\section{METODE PENELITIAN}

Metode yang digunakan dalam penelitian ini adalah metode deskripsi. Metode ini dilakukan dengan mendeskripsikan faktafakta yang kemudian diikuti dengan analisis. Pendekatan penelitian yang digunakan adalah pendekatan kualitatif. Pendekatan ini digunakan untuk membuat deskriptif, gambaran, atau lukisan secara sistematis, faktual dan akurat mengenai fakta-fakta, sifat-sifat serta hubungan antarfenomena yang dimiliki. Data penelitian ini adalah tulisan yang diperoleh dari dokumentasi yang berbentuk catatan atau buku. Data dari penelitian ini berupa ujaran atau pernyataan para tokoh dalam buku kisah inspiratif Indonesia Mengajar, sedangkan sumber data penelitian berasal dari buku kisah inspiratif Indonesia mengajar. Pengumpulan data dilakukan dengan menggunakan teknik dokumentasi. Dalam pengumpulan data, peneliti mencermati tiap ujaran atau pernyataan para 
tokoh dalam kisah inspiratif Indonesia mengajar kemudian mengidentifikasi ragam bahasa yang digunakan para tokoh untuk dianalisis. Analisis data penelitian ini dilakukan dengan cara proses mencari dan menyusun data secara sistematis data yang diperoleh dari hasil wawancara, catatan lapangan, dan dokumentasi, dengan cara mengorganisasikan data ke dalam kategori, memilih mana yang penting dan yang akan dipelajari, dan mambuat kesimpulan sehingga mudah dipahami oleh diri sendiri maupun orang lain.

\section{HASIL DAN PEMBAHASAN}

Variasi bahasa dalam kisah inspiratif Indonesia Mengajar dapat dilihat dari empat segi, yaitu (1) variasi bahasa dari segi penutur; (2) variasi bahasa dari segi pemakaian; (3) variasi bahasa dari segi keformalan; dan (4) variasi bahasa dari segi sarana.

\section{Variasi bahasa dari segi penutur}

Dalam kisah inspiratif Indonesia mengajar, pemilihan atau penggunaan variasi bahasa bergantung pada penuturnya. Dari hasil analisis data yang dilakukan, para penutur dalam kisah inspiratif Indonesia mengajar, berasal dari berbagai daerah atau wilayah. Selain itu, para penutur juga dari berbagai usia, dan dari berbagai tingkat pendidikan, sehingga penggunaan bahasa juga berbeda-beda sesuai faktor yang telah disebutkan. Peneliti akan memaparkan bentuk-bentuk variasi bahasa dari segi penutur yang digunakan oleh masyarakat Bengkalis (Riau), Kab. Halmahera Selatan (Maluku Utara), Kab. Kab. Majene (Sulawesi Barat), Kab. Paser (Kalimantan Timur), Kab. Tulang Bawang Barat (Lampung), serta yang digunakan oleh penutur dari Jawa yang terdapat dalam kisah inspiratif Indonesia mengajar.

Bentuk variasi bahasa dari segi penutur yang digunakan oleh masyarakat Halmahera Selatan yang terdapat dalam kisah inspiratif Indonesia mengajar, ditemukan adanya dialek ube, pe, kase, so, i, tak lah, tara, papa, kok, ga, dong, sih, gitu, gini, bener, aja, deh, sebentar, pigi, iyo, walah, pengin, udah, nulis, in, ketemu, ngulang, banget, ama. Selain dialek, bentuk variasi bahasa dari segi penutur, ditemukan juga adanya sosiolek ngana, kitorang, lu, gue, tak, mamak, pak, bu, nak.

\section{Variasi bahasa dari segi pemakaian}

Variasi bahasa dari segi pemakaian berkenan dengan penggunaannya, pamakaianannya, atau fungsinya. Variasi bahasa yang digunakan berbeda-beda sesuai dengan kebutuhan dalam bidang-bidang tertentu. Berdasarkan hasil analisis data pada kisah inspiratif Indonesia mengajar, variasi bahasa dari segi pemakaian ditemukan dalam bidang sastra yang meliputi kosakata puisi, lirik, nyanyian, lantunan melodi dan harmoni, mendendangkan, bait, baris, nada, irama, koda, karya seni.

Dalam setiap bidang kegiatan biasanya mempunyai kosakata khusus yang tidak digunakan dalam bidang lain. Maka, kosakata-kosakata yang disebutkan di atas, hanya digunakan pada bidang sastra. Pemilihan atau penggunaan kata puisi, lirik, nyanyian, lantunan melodi dan harmoni, mendendangkan, bait, baris, nada, irama, koda, dan karya seni tidak digunakan pada bidang militer, jurnalistik, perekonomian dan perdangangan atau yang lain, tetapi hanya digunakan pada bidang sastra.

\section{Variasi bahasa dari segi keformalan}

Variasi bahasa dari segi keformalan, berdasarkan hasil analisis data ditemukan ragam usaha atau ragam konsultatif digunakan para penutur dalam pembicaraan biasa di sekolah dan rapat-rapat yang pembicaraannya berorientasi pada hasil. Kemudian, ragam akrab atau ragam inti yang digunakan oleh para penutur yang memiliki hubungan akrab untuk berkomunikasi. Dalam kisah inspiratif Indonesia mengajar juga ditemukan ragam santai atau ragam kasual yang digunakan dalam situasi tidak resmi untuk berbincang- 
bincang dengan keluarga, teman karib pada waktu istirahat, berekreasi dan sebagainya yang berupa alegro meliputi, so, pe, pigi, tau, ga, wis, nak, pa, bu.

\section{Variasi bahasa dari segi sarana}

Variasi bahasa dari segi sarana, ditemukan adanya sarana tulis yaitu berupa puisi yang ditulis murid-murid kepada gurunya dalam rangka memperingati Hari Guru, surat yang ditulis murid-murid untuk gurunya dan lagu yang dituliskan oleh para pengajar muda.

Dari hasil analisis data, alasan pemilihan atau penggunaan suatu ragam bahasa dalam bertutur atau berkomunikasi yang dilakukan oleh para penutur dalam kisah inspiratif Indonesia mengajar didasarkan pada berbagai hal, beberapa di antaranya adalah situasi, kebiasaan, pendidikan, dan mitra tutur.

Terdapat dua situasi dalam kisah inspiratif Indonesia mengajar, antara lain situasi formal dan situasi nonformal. Namun, dalam situasi formal seperti pembelajaran di sekolah, rapat guru, pertemuan antara guru dan orang tua murid, para penutur tidak menggunakan ragam bahasa formal, mereka menggunakan ragam usaha atau ragam konsultatif yang dikatakan bahwa merupakan ragam bahasa yang paling operasional, yang wujudnya berada di antara ragam formal dan ragam informal. Bisa dilihat pada percakapan para guru pada rapat diadakan di sebuah sekolah, sebagai berikut

A : "Coba bilang ke anak, Bu, kalau ada penghargaan pada akhir bulan untuk anak yang paling sedikit izin ke belakang. Jadi, yang dapat reward nggak harus anak yang dapat nilai tertinggi di kelasnya saja.

B : "Bagaimana cara mengontrol anak yang bikin ulah atau suka berkata jorok di kelas?"

A : "Layaknya main bola, siapa yang dapat kartu kuning dua kali, akan mendapat kartu merah dan ia harus keluar dari kelas. Kandidat yang mendapat kartu kuning siapa saja? Mereka yang ngomong jorok dan ibu guru mendengarnya, mereka yang ringan tangan, atau suka menempeleng teman, dan mereka yang makan di kelas. Ibu bisa tambahkan yang lainnya.

Dari percakapan di atas, dapat dilihat bahwa dalam rapat sekolah yang ada dalam situasi formal, para penurut tidak menggunakan bahasa yang formal saja, tetapi mereka juga menggunakan ragam bahasa santai. Dapat dilihat pada pemilihan atau penggunaan kata nggak dan ngomong pada percakapan di atas. Kemudian, situas nonformal, penggunaan ragam bahasa dapat dilihat pada percakapan-percakapan para penutur yang terjadi di rumah, di jalan, dan sebagainya.

Mitra tutur juga merupakan salah satu faktor pemilihan atau penggunaan ragam bahasa dalam berkomunikasi. Dalam kisah inspiratif Indonesia mengajar, ada penutur yang berasal dari Jawa kemudian tinggal sementara di daerah lain. Dalam berkomunikasi dengan masyarakat di daerah yang ia tempati kini, ia akan menggunakan ragam bahasa yang digunakan oleh masyarakat di daerah itu. Misalnya, komunikasi seorang pengajar muda yang berasal dari Jawa dengan mitra tuturnya murid-murid yang berasal dari Halmahera Selatan. Ada pemilihan katakata yang digunakan pengajar muda itu dalam berkomunikasi yang dimengerti oleh mitra tuturnya karena ragam bahasa yang digunakan merupakan ragam bahasa yang dimengerti dan digunakan oleh masyarakat di Halmahera Selatan.

\section{SIMPULAN}

Berdasarkan penelitian yang telah dilakukan mengenai ragam bahasa dalam kisah inspiratif Indonesia mengajar, disimpulkan bahwa ragam bahasa yang digunakan penutur dalam berkomunikasi dengan mitra tutur adalah variasi bahasa dari segi penutur, yakni ragam bahasa yang 
digunakan oleh para penutur dengan mitra tuturnya adalah ragam dialek. Para penutur sering menggunakan dialek daerahnya dalam berkomunikasi; variasi bahasa dari segi pemakaian. Berdasarkan segi keformalan, ragam bahasa yang digunakan dalam kisah inspiratif Indonesia mengajar adalah ragam bahasa dalam bidang sastra; variasi bahasa dari segi keformalan, yakni ragam bahasa yang digunakan para penutur dalam kisah inspiratif Indonesia mengajar adalah ragam resmi atau ragam formal, ragam usaha atau ragam konsultatif, ragam santai atau ragam kasual, dan ragam akrab atau ragam intim; dan variasi bahasa dari segi sarana. Dalam kisah inspiratif Indonesia mengajar, terdapat ragam lisan dan tulis.

\section{DAFTAR PUSTAKA}

Alwi, Hasan, dkk. 2010. Tata Bahasa Baku Bahasa Indonesia. Jakarta: Pusat Bahasa dan Balai Pustaka.

Chaer dan Agustina. 2004. Sosiolinguistik Perkenalan Awal. Jakarta: Rineka Cipta.

Irjayanti, Erwin dkk. 2011. Indonesia Mengajar. Yogyakarta: Bentang
Mufidah, M. 2014. Metodologi Penelitian. http://digilib.uinsby.ac.id/1535/8/Bab\% 203.pdf. Diakses pada 20 Agustus 2017.

Nadhifah, Nailatina. 2015. Sosiolinguistik. http://nailatinnadhifah.blogspot.co.id/2 015/03/hakikat-sosiolinguistikmenurut-para.html. Diakses pada 15 Januari 2018.

Setiawan, Parta. 2015. Definisi Bahasa Menurut Para Ahli. http://www.gurupendidikan.co.id/15definisi-bahasa-menurut-para-ahli/. Diakses pada 15 Januari 2018.

Sumarsono. 2011. Sosiolinguistik. Yogyakarta: Pustaka Pelajar.

Tawar, S. 2014 Landasan Teori. http://digilib.unila.ac.id/1466/8/BAB\% 20II.pdf. Diakses pada 11 Agustus 2017.

Wijana dan Rohmadi. 2010. Sosiolinguistik Kajian Teori dan Analisis. Yogyakarta: Pustaka Pelajar.

Wibisono, Bambang. 2017. Varian Bahasa Orang Madura di Jember dalam Komunikasi Lisan Tidak Resmi. Jember: Jurnal Bahasa, Sastra, Seni dan Pengajarannya. Tahun 35, Nomor 2:158-166 